\title{
Productivity and Quality of Hybrid Canola Oil and Seeding Time
}

Alison A. Schmatz ${ }^{1}$, Pedro H. Weirich Neto ${ }^{2}$, Lucas H. Waiga ${ }^{3}$, Maria E. P. Arrua ${ }^{4}$, Sandra R. M. Antunes ${ }^{5}$, Nátali M. de Souza ${ }^{6}$, David de S. Jaccoud Filho ${ }^{7}$, Ayrton Berger Neto $^{8}$, Augusto C. Antunes ${ }^{9}$

${ }^{1,2,4,5,9}$ Programa de Pós Graduação em Bioenergia, Universidade Estadual de Ponta Grossa,4748 General Carlos Cavalcanti Av., Zip code 84030-900, Uvaranas, Ponta Grossa, Paraná, Brazil

${ }^{2,6}$ Laboratório de Mecanização Agrícola (Lama), Bloco F - Sala 4, 4748 General Carlos Cavalcanti Av., Zip code 84030-900, Uvaranas, Ponta Grossa, Paraná, Brazil

${ }^{3,4,5,9}$ Departamento de Química, Bloco M - Sala 31, 4748 General Carlos Cavalcanti Av., Zip code 84030-900, Uvaranas, Ponta Grossa, Paraná, Brazil

${ }^{7,8}$ Laboratório de Fitopatologia Aplicada, Bloco F - Sala 10, 4748 General Carlos Cavalcanti Av., Zip code 84030-900, Uvaranas, Ponta Grossa, Paraná, Brazil

\begin{abstract}
Biofuels are the main alternative for changing the world's energy matrix, which is now centralized in fossil fuels. The characterization of alternative sources of biomass, mainly regionally, shapes database for decision making.For this purpose, a factorial experiment was carried out with three canola cultivars (Hyola 43, 61 and 571), seeded in four times (April 4th, April 16th, May 2nd and May 14th).As biomass characterization, grain yield, oil content and yield, specific mass, oxidative stability, acidity and lipid profile were determined. There was significant difference for the hybrids in the variables oil content, induction time and in the stearic, linoleic and linolenic contents. The highlight was the hybrid Hyola 43.There was significant difference for the periods in the grain yield, oil content, oil yield, and induction time and in the palmitic, stearic, oleic and linoleic contents. Considering values of dependent, quantitative and qualitative variables, the best seeding season of canola would be between the second fortnight of April and the first week of May.
\end{abstract}

Keywords_Biodiesel, vegetable oils, fatty acid.

\section{INTRODUCTION}

Directly or indirectly biomass is the basis for alternative energies. The biomass is responsible for $14 \%$ of world energy used [1].

For the production of biodiesel, biomass (raw material) is the most important and costly part of the process. In Germany, the main producer and consumer of biodiesel in the world, and in the European Union, canola accounts for $80 \%$ and $60 \%$, respectively, of the cultivation of oilseeds for this purpose[2].The planted area with canola in Brazil in 2015 was 53,610 ha, an expansion of $8 \%$ in relation to the previous harvest [3].

Oil crops for the production of biofuels must offer good oil yield and physicochemical characteristics consistent with use and current standards [2]. The determination of the fatty acid profile is one of the main characterizations of an oilseed.The main fatty acid found in canola oil is the oleic acid, also known as Omega-9[4].

An issue in biofuels, oxidative stability is closely related to the structure of fatty acid chains, being more susceptible those with a higher proportion of unsaturated lipids[5].Canola oil has a high percentage of unsaturated fats, close to 93\% [6].

The natural decomposition of triglycerides can be accelerated by light and heating, and rancidity is almost always followed by the formation of free fatty acids. High levels of acidity reflect in negative effects on oils, which may make them inappropriate for food or even for fuel purposes.

The mentioned characteristics may vary according to genetics and the environment agricultural management and environmental, such as water availability and frost, are control variables in the qualitative and quantitative yield of canola[7, 8]. 


\section{MATERIAL AND METHOD}

The field experiment was conducted in the municipality of Tibagi, state of Paraná, with the approximately coordinates $24^{\circ}$ $16^{\prime} 29^{\prime \prime}$ South and $50^{\circ} 05^{\prime} 42^{\prime \prime}$ 'West, and average elevation of $952 \mathrm{~m}$. The experiment consisted of two factors, seeding times (four) and canola (Brassica napus) hybrids (three). The experiment was conducted in randomized blocks. The seeding times were: April 4th, April 16th, May 2nd and May 14th.The used hybrids were Hyola 43, Hyola 61 and Hyola 571.

At the seeding time, we used 18 seeds per meter and spacing between rows of $0.45 \mathrm{~m}$. There was applied, in the furrow, 100 $\mathrm{kg} \mathrm{ha}^{-1}$ of fertilizer (NPK formula 13-33-00). On the 45th day after seeding, there were applied, on total area, $100 \mathrm{~kg} \mathrm{ha}^{-1}$ of urea and $100 \mathrm{~kg} \mathrm{ha}^{-1} \mathrm{ofKCl}$. During the crop cycle no fungicides, insecticides or herbicides were applied.

For the monitoring of the climatic conditions during the crop development, information on minimum, maximum, daily mean and cumulative rainfall index were used. They were recorded in a meteorological station of IAPAR - Instituto Agronômico do Paraná, located in the TelêmacoBorba city (approximate coordinates: latitude $24^{\circ} 20^{\prime} \mathrm{S}$ - longitude $50^{\circ} 37^{\prime} \mathrm{W}$ ).

For oil and biodiesel characterization, $150 \mathrm{~g}$ of seeds were ground in a Willey knife mill, with 20 mesh sieve.For lipids extraction, a Soxhlet apparatus was used, using n-hexane as solvent, for 6 hours.

The obtained oil was submitted to an aqueous degumming process, aiming to remove phosphatides, by adding $5 \%$ of water mass in relation to the total lipid mass. The mixture was stirred for 30 minutes, at $65^{\circ} \mathrm{C}$, in a refrigerated ultracentrifuge, Hitachi Himac, model CR21GII.The mixture was subjected to $5000 \mathrm{rpm}$ at a constant temperature of $4{ }^{\circ} \mathrm{C}$ for 15 minutes.

After degumming the lipid specific mass was determined, at $20^{\circ} \mathrm{C}$, using the Anton Paar digital densimeter, model DMA $4500 \mathrm{M}$.

The oxidative stability was determined in an accelerated oxidation test, under a temperature of $110{ }^{\circ} \mathrm{C}$ and $10 \mathrm{~L} \mathrm{~h}-{ }^{1}$ airflow, with RancimatMetrohm apparatus, model 893.The acid index was determined according to [9].

The biodiesel production process was carried out by mixing $0.0675 \mathrm{~g}$ of sodium methoxide dissolved in $5 \mathrm{ml}$ of methanol and added in $10 \mathrm{ml}$ of oil. The reaction mixture was kept under constant stirring and heating at $55^{\circ} \mathrm{C}$ for one hour. After resting for 30 minutes the glycerol was removed, were performed two steps of aqueous washing and drying with anhydrous calcium chloride and washing with organic solvent (petroleum ether)[10].

The biodiesel was evaluated by Nuclear Magnetic Resonance Spectroscopy ${ }^{1} \mathrm{H}-\mathrm{RMN}$, with deuterated chloroform as solvent, with a BRUKER ASCEND spectrometer, of $400 \mathrm{MHz}$.

Chromatographic analyzes were performed on a Perkin-Elmer Gaseous Chromatograph, Clarus 580, with FID detector, capillary column type Elite-Wax, $60 \mathrm{~m}$ long, $0.25 \mathrm{~mm}$ in diameter and with a stationary phase of $0.5 \mathrm{~mm}$ thickness. Heating ramp with initial temperature of $190^{\circ} \mathrm{C}$, heating rate of $10^{\circ} \mathrm{C} \mathrm{min}-{ }^{1}$ to $250{ }^{\circ} \mathrm{C}$ was used. An injection volume of $1.0 \mathrm{~mL}$ of sample in hexane and internal standard methyl nonadecanoate was used.

All dependent variables were submitted to the F test for analysis of variances and, when pertinent, Tukey's regression analysis and mean test were performed. The Sisvar software was used for the analysis, version 5.3[11].

\section{RESULTS AND DISCUSSION}

The temperatures observed during the experiment conduction are shown in Fig. 1. In the initial stage, from emergence to flowering, temperatures of 13 to $22{ }^{\circ} \mathrm{C}$ are recommended [6]. At this stage, for the first and second seeding season, temperatures were higher, which may have led to lower productivity.

According to the stadium basal temperatures are different, for example, there were determined for canola $-0,8^{\circ} \mathrm{C}$ for vegetative stage stadium and $10,0^{\circ} \mathrm{C}$ for flowering [8]. Therefore all seeding times were harmed. Low temperatures, with frost occurrence, at the start of flowering can reduce up to $50 \%$ of flowering, whereas frostings at the end of flowering can reduce from 80 to $100 \%$ of flowering [7]. The only negative temperatures cataloged were recorded on July 25th, the only day 
where the mean temperature was also below $5{ }^{\circ} \mathrm{C}$ (Fig. 1). This may have adversely affected the first and second seeding seasons

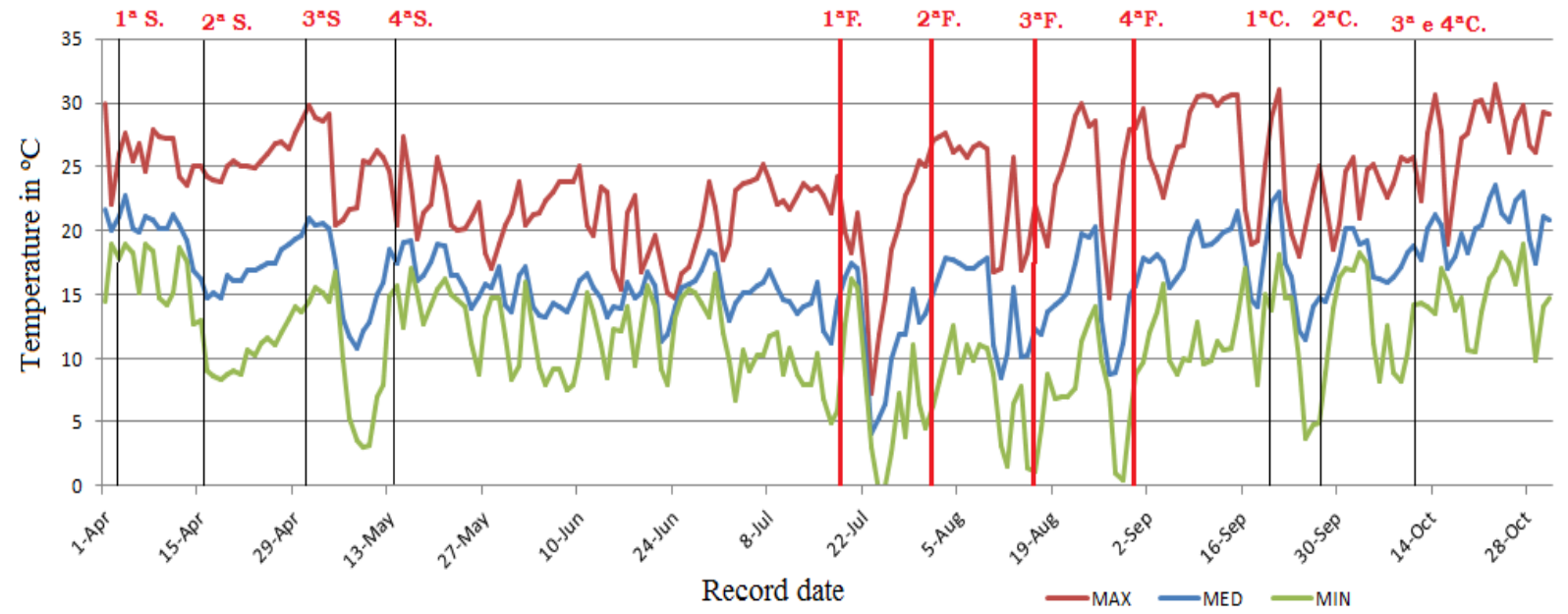

FIGURE 1- Minimum, maximum and mean temperatures from April to October 2013, meteorological station of the InstitutoAgronômico do Paraná, in TelemacoBorba, latitude: $24^{\circ} 20 ' S$ - longitude: $5^{\circ} \mathbf{3 7}^{\prime} \mathrm{W}$ - altitude 768m.

Note: "S"-seeding time; " $F$ "- approximate date of end of flowering; " $C$ "-crop date

When the temperature of the air rises above $27^{\circ} \mathrm{C}$, thermal stress occurs in the crop, reducing or even inhibiting the canola processes of growth and development, mainly in the final period of flowering and initial filling of the grains [12]. This is what happened to the fourth seeding season. Water stress at the end of flowering and beginning of grain filling has negative effects on the concentration of oil in the grain [13].As the beginning of flowering and the duration of this period may vary a few days, it was considered that there was no water stress (Fig. 2).

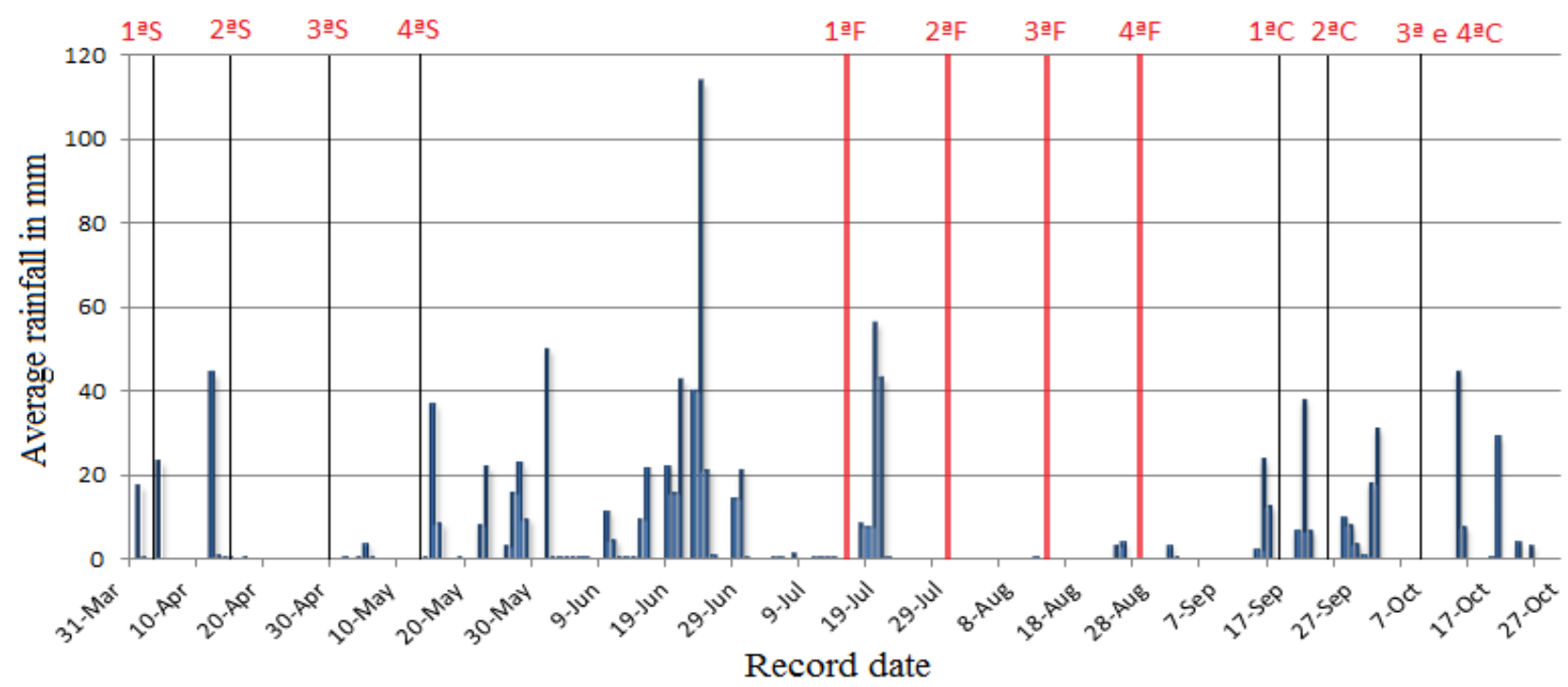

FIGURE 2- Daily precipitation from the months of April to October 2013, collected from themeteorological station of the InstitutoAgronômico do Paraná, in TelemacoBorba, latitude: $24^{\circ} 20 ' \mathrm{~S}$ - longitude: $50^{\circ} 37^{\prime} \mathrm{W}$ - altitude 768m.

Note: "S"- seeding time; “F”- approximate date of end of flowering; “ $C$ "-crop date

The productive potential of an agricultural crop is defined through genotype-environment interaction. According to analysis of variance, the grain yield variable did not present a significant difference for the hybrid factor, but there was a significant difference $(\mathrm{p}<0.01)$ for the seeding time factor, and no significant difference was observed for the interaction of the factors and for the blocks (Table 1). 


\section{TABLE 1}

Grain Yield, Oil Content, Oil Yield, Oil Specific Mass, Induction Time (Oxidative Stability) and Acidity of the Oil and Test of Means, When Pertinetes, of the Three Canola Hybrids

\begin{tabular}{|c|c|c|c|c|c|c|}
\hline Hybrid & $\begin{array}{c}\text { Productivity } \\
\mathbf{k g ~ h a}^{-1}\end{array}$ & $\begin{array}{c}\text { Oil content* } \\
\mathbf{g ~ k g}^{-1}\end{array}$ & $\begin{array}{c}\text { Oil yield } \\
\mathbf{k g ~ h a}^{-1}\end{array}$ & $\begin{array}{c}\text { Specific } \\
\text { mass } \\
\mathbf{k g ~ m}^{-3}\end{array}$ & $\begin{array}{c}\text { Induction } \\
\text { time* } \\
\mathbf{h}\end{array}$ & $\begin{array}{c}\text { Acidity } \\
\mathbf{m g ~ K O H ~}^{-\mathbf{1}}\end{array}$ \\
\hline Hyola 43 & $1,556.90$ & $382.7 \mathrm{a}$ & 641.8 & 901.0 & $9.95 \mathrm{~b}$ & 1.70 \\
\hline Hyola 61 & $1,703.17$ & $350.4 \mathrm{~b}$ & 616.9 & 898.0 & $8.66 \mathrm{a}$ & 1.72 \\
\hline Hyola 571 & $1,663.76$ & $370.6 \mathrm{ab}$ & 716.2 & 899.0 & $9.50 \mathrm{~b}$ & 1.61 \\
\hline
\end{tabular}

*means followed by equal letters in the columns do not differ from each other to 0.05 of probability by the Tukey test.

Linear regression analysis showed a positive relationship between time and yield (Fig. 3a). The canola seeded on April 4th reached the lowest productivity, with an mean of $382 \mathrm{~kg} \mathrm{ha}^{-1}$. The effect of the high temperatures recorded for this month and the occurrence of frost at the end of flowering/beginning of filling caused a negative impact (Fig. 1).

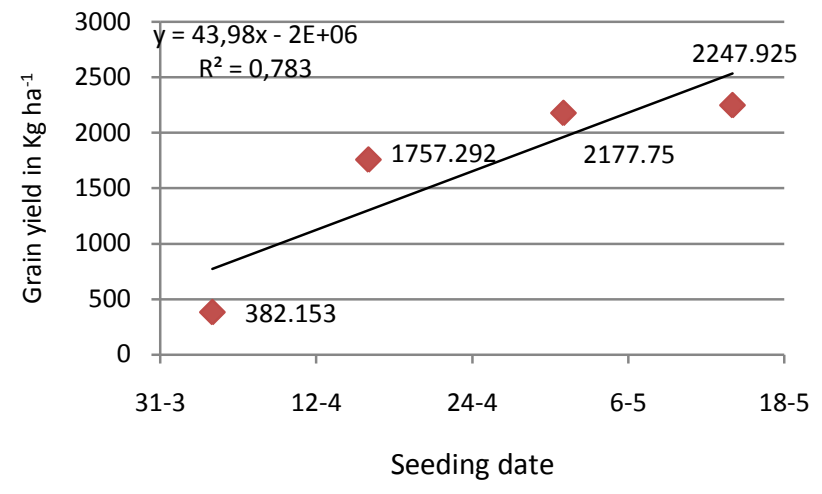

(a)

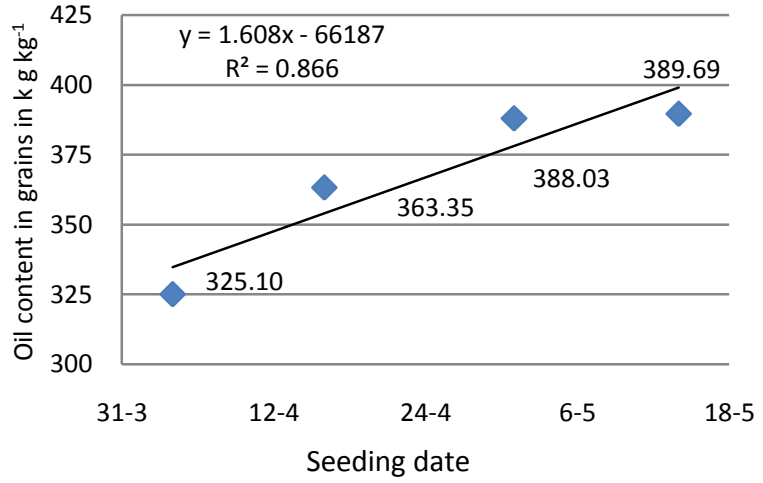

(b)

FIGURE 3 - Values found and adjusted regression for grain yield (a) and oil content (b) for Hyola hybrids 43, 61 and 571, according to seeding dates. Tibagi, PR.

The mean yield of canola grains in the State of Paraná in the 2011 harvest was $1,368 \mathrm{~kg} \mathrm{ha}^{-1}$, while the 2012 harvest was 813 $\mathrm{kg} \mathrm{ha}^{-1}$, due to strong frost. The harvest of $2013 \mathrm{had}$ an average of $1,436 \mathrm{~kg} \mathrm{ha}^{-1}$ [14].

In contrast, in experiments performed in Aw climate, with mild temperatures, with nine canola varieties, using flowering irrigation, yields ranged from $1,494 \mathrm{~kg} \mathrm{ha}^{-1}$ to $2,268 \mathrm{~kg} \mathrm{ha}^{-1}[15]$. In this case, the authors related terminal flower abortion and lower filling of the siliquas with elevation of temperature.

The variable oil content showed a significant difference for the hybrid factors and time $(\mathrm{p}<0.01)$, showing no difference for the interaction of the factors. The mean lipid value expected in Brazil is $380 \mathrm{~g} \mathrm{~kg}^{-1}$ [6]. In Cfa climate, varying sowing dates, [16] obtained, for two hybrids, values between 346 and $399 \mathrm{~g} \mathrm{~kg}^{-1}$. This variation, according to the authors, was correlated with water stress.

The mean for the Hyola 43 hybrid was statistically equal to the Hyola 571 hybrid and higher than the Hyola 61 hybrid.The Hyola 571 hybrid was statistically equal to the Hyola 61 hybrid (Table 1).In this case, there was a positive linear relationship between grain oil content and seeding time (Fig. 3b).The mean temperature increase in the filling stage of the grains can provide deformities and decrease in oil content [17].As was the case with seeding seasons 1 and 2.

The canola seeded in the first season may have its oil content reduced due to the low temperatures, below $5{ }^{\circ} \mathrm{C}$, observed in the second half of July, which also presented negative temperatures (Fig. 1). At that time, the crop was at the end of the flowering phase and beginning of the grains filling, critical phases to the crop [13].

According to analysis of variance, the variable oil yield per area did not present a significant difference for the hybrid factor (Table 1), but there was a significant difference $(\mathrm{p}<0.01)$ for the seedingtime factor (Fig. 4a), with no difference for the interaction between the factors. There was a positive linear correlation between the oil yield per area and the seeding times. These values are consequences of the productivities and oil content present already presented and discussed.

The variance analysis showed a significant difference for the induction time (oxidative stability) for the factors hybrid (Table 1) and time $(\mathrm{p}<0.01)$ (Fig. 4b). There was no significant difference for the factors interaction. The hybrids Hyola 43 and 
Hyola 571 were statistically equal and superior to the hybrid Hyola 61. The values can be considered coherent compared to [18] that obtained a mean of 7.2 hours. There was a tendency to increase the induction time with seeding times. Oxidative stability was affected by climatic conditions, especially in the case of the first seeding season.

The specific mass did not present significant difference for the hybrid factors and times, with mean value of $899.3 \mathrm{~kg} \mathrm{~m}{ }^{-3}$ (Table 1).According to [19] the value of the specific mass of canola lipids is $878 \mathrm{~kg} \mathrm{~m}^{-3}\left(25^{\circ} \mathrm{C}\right)$. For different temperatures, [20] found a variation of $908 \mathrm{~kg} \mathrm{~m}^{-3}\left(10^{\circ} \mathrm{C}\right)$ to $921 \mathrm{~kg} \mathrm{~m}^{-3}\left(30^{\circ} \mathrm{C}\right)$.

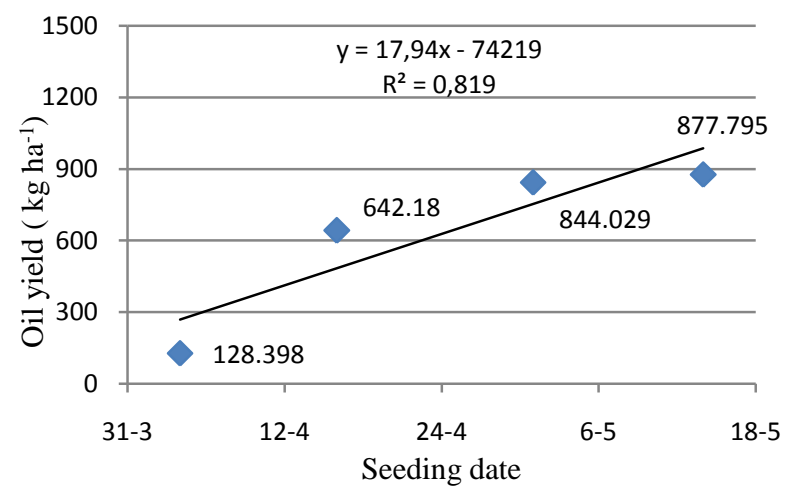

(a)

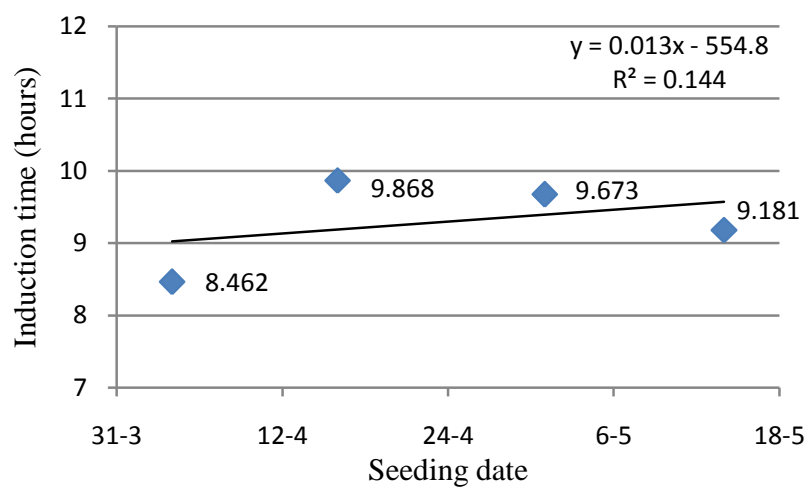

(b)

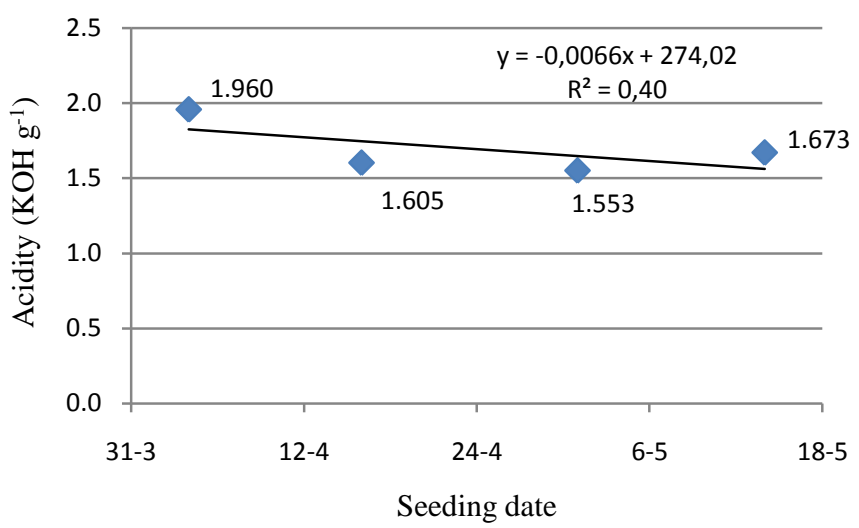

(c)

FIGURE 4 -Values and adjusted regression for oil yield (a), induction time (b) and acidity (c) for Hyola hybrids 43, 61 and 571, according to sowing dates. Tibagi, PR.

The variable acidity did not present significant differences for the hybrid factor (Table 1), while there were significant differences for the time factor $(\mathrm{p}<0.05)$, and no significant difference was observed for the interaction (Fig. 4c). The values found may be high. Evaluating crude and degummed canola oil, [21] obtained values of $1.08 \mathrm{mg} \mathrm{KOH} \mathrm{g}^{-1}$ and $0.53 \mathrm{mg} \mathrm{KOH}$ $\mathrm{g}^{-1}$, respectively.

The fatty acids determined were palmitic, stearic, oleic, linoleic and linolenic. The palmitic acid variable (C 16:0) did not present a significant difference for the hybrid factor (Table 2), whereas there was a significant difference for the time factor $(\mathrm{p}<0.01)$.

\section{TABLE 2}

Relative Mass of Palmitic, Stearic, Oleic, Linoleic and Linolenic Fatty Acids and Test of Mean (Tukey), When Applicable, of Three Hybrids of Canola. Tibagi, PR.

\begin{tabular}{|l|c|c|c|c|c|}
\hline \multirow{2}{*}{ Hybrid } & $\begin{array}{c}\text { Palmitic } \\
(\mathbf{C ~ 1 6 : 0 )} \\
\mathbf{g ~ k g}^{-1}\end{array}$ & $\begin{array}{c}\text { Stearic } \\
(\mathbf{C ~ 1 8 : 0 ) *} \\
\mathbf{g ~ k g ~}^{-1}\end{array}$ & $\begin{array}{c}\text { Oleic } \\
(\mathbf{C ~ 1 8 : 1 )} \\
\mathbf{g ~ k g}^{-1}\end{array}$ & $\begin{array}{c}\text { Linoleic } \\
(\mathbf{C ~ 1 8 : 2})^{*} \\
\mathbf{g ~ k g}^{-1}\end{array}$ & $\begin{array}{c}\text { Linolenic } \\
(\mathbf{C} ~ 18: 3) * \\
\mathbf{g ~ k g}^{-1}\end{array}$ \\
\hline Hyola 43 & 46.7 & $28.7 \mathrm{a}$ & 644.8 & $195.4 \mathrm{a}$ & $77.3 \mathrm{a}$ \\
\hline Hyola 61 & 46.2 & $25.5 \mathrm{~b}$ & 652.1 & $172.4 \mathrm{~b}$ & $92.8 \mathrm{~b}$ \\
\hline Hyola 571 & 43.5 & $28.3 \mathrm{a}$ & 654.2 & $176.1 \mathrm{~b}$ & $86.3 \mathrm{ab}$ \\
\hline
\end{tabular}

*means followed by equal letters in the columns do not differ from each other to 0.05 of probability by the Tukey test. 
Regarding the temporal evaluation, there was a tendency to decrease the palmitic content (C16:0) with advance in the seeding dates (Fig. 5a).Evaluating two varieties of canola, and two varieties of rapeseed, [22] found values of $80.8 \mathrm{~g} \mathrm{~kg}$ and $59.0 \mathrm{~g} \mathrm{~kg}^{-1}$ in canola and $47.8 \mathrm{~g} \mathrm{~kg}^{-1} \mathrm{e} 39.8 \mathrm{~g} \mathrm{~kg}^{-1}$ in rapeseed. [23] found the presence of $39.0 \mathrm{~g} \mathrm{~kg}^{-1}$ palmitic acid in canola oil.

The stearic acid variable (C18:0) presented a significant difference for the hybrid factors and times ( $\mathrm{p}<0.01$ ), and no significant difference was observed for the interaction. The highest concentrations of stearic acid were found in the Hyola 43 and 571 hybrids, 28.71 and $28.29 \mathrm{~g} \mathrm{~kg}^{-1}$, respectively. The hybrid Hyola 61 obtained the lowest concentration; $25.5 \mathrm{~g} \mathrm{~kg}^{-1}$ (Table 2).Fig. $5 \mathrm{~b}$ shows the concentrations of stearic acid according to sowing time.

Comparing stearic acid in canola and rapeseed, [22] obtained 16.9 and $16.5 \mathrm{~g} \mathrm{~kg}$-1 for canola, and 20.2 and $25.0 \mathrm{~g} \mathrm{~kg}{ }^{-1}$ for rapeseed. [23] Found $16.0 \mathrm{~g} \mathrm{~kg}^{-1}$ canola.

The variable oleic acid (C18:1) showed a significant difference for the time factor $(\mathrm{p}<0.01)$, whereas no significant differences were observed for the hybrid factor, and no significant difference was observed for the interaction. The mean concentration of this lipid found in the hybrids was $650.4 \mathrm{~g} \mathrm{~kg}^{-1}$ (Table 2).

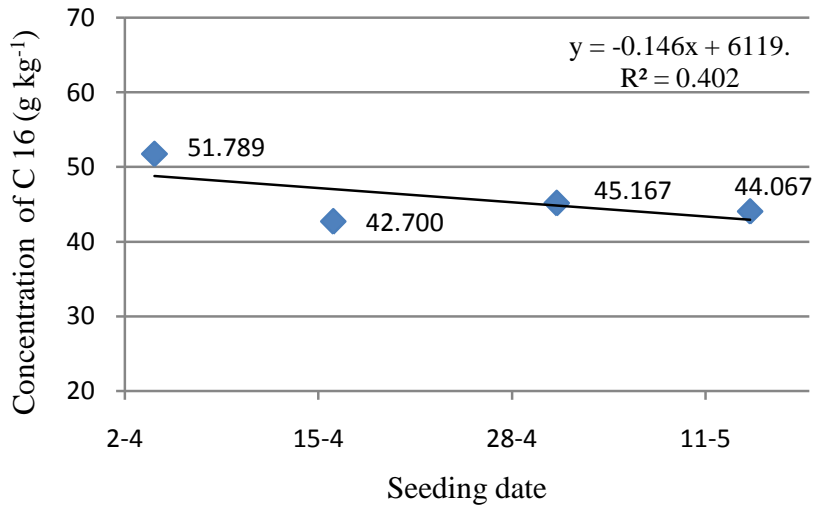

(a)

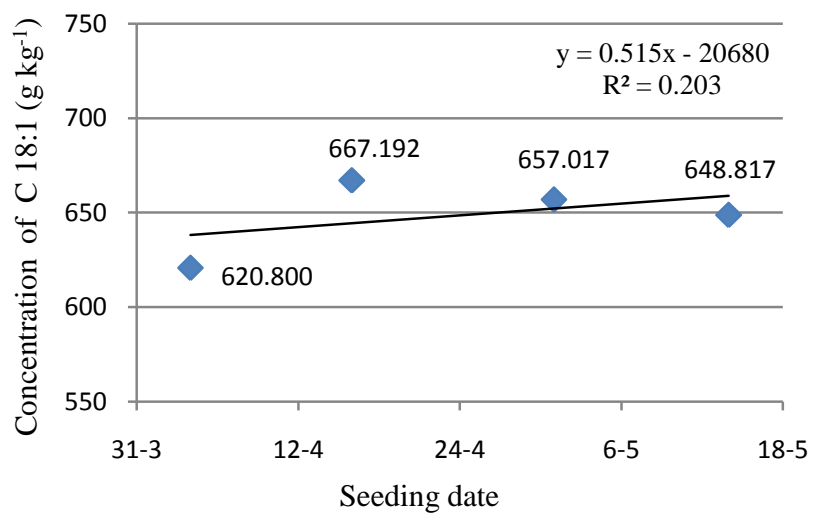

(c)

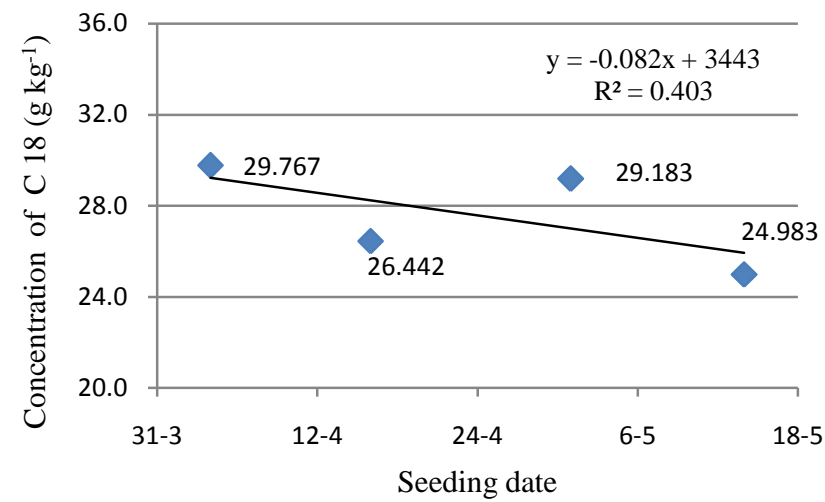

(b)

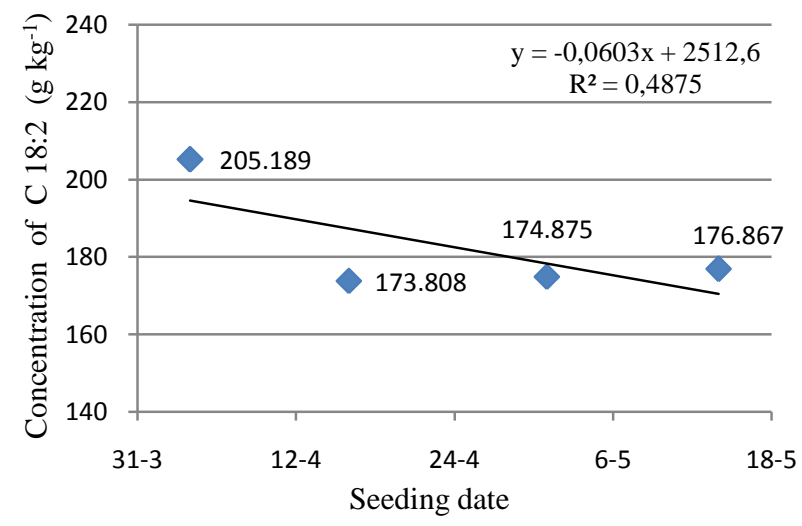

(d)

FIGURE 5 -Values and adjusted regression for C16:0 (a), stearic (C18:0) (b), oleic (18:1) (c) and linoleic acid (18:2), 61 and 571, according to sowing dates. Tibagi, PR

Although the equations represented (Fig. 5) were significant, the mathematical adjustments presented a low R2 value, so the seeding time can influence in approximately $20 \mathrm{~g} \mathrm{~kg}^{-1}$ for oleic (18:1) and $30 \mathrm{~g} \mathrm{~kg}^{-1}$ linoleic (18: 2).

The concentration of oleic tended to increase as the seeding dates progressed (Fig. 5c).Studying canola and rapeseed, [22]

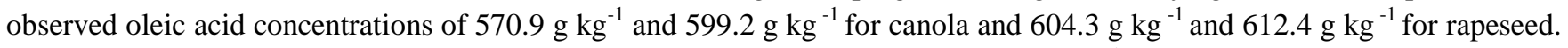
[23] Studying commercially available oils (Illinois, USA), found for canola $600 \mathrm{~g} \mathrm{~kg}^{-1}$. [24] evaluated twenty edible oils observed the presence of $620 \mathrm{~g} \mathrm{~kg}^{-1}$ oleic in canola.

Oleic acid, also known as omega-9, has only one unsaturation, being one of the healthiest sources of dietary fat [25]. The oleic acid values found in this experiment are higher than most cited in the correlative literature. 
According to analysis of variance, the variable linoleic acid (C 18:2) presented significant differences for the hybrid and period factors, whereas no significant difference was observed for the interaction. The hybrid Hyola 43 had the highest concentration of this fatty acid, mean of $195.4 \mathrm{~g} \mathrm{~kg}^{-1}$. The concentrations in Hyola 61 and 571 hybrids were 172.4 and 176.0 $\mathrm{g} \mathrm{kg}^{-1}$, respectively (Table 2). Linoleic acid also known as omega-6 plays a key role in maintaining human health.

Qualifying canola and rapeseed varieties, [22] found 231.2 and $230.7 \mathrm{~g} \mathrm{~kg}^{-1}$ of linoleic acid to canola and 232.7 and $236.3 \mathrm{~g}$ $\mathrm{kg}^{-1}$ to rapeseed, and [23] found $220 \mathrm{~g} \mathrm{~kg}^{-1}$ of linoleic acid in canola. The linoleic acid values found in this experiment are lower than those reported.

The linolenic acid variable (C 18:3) presented a significant difference for the hybrid factor, and no significant differences were observed for the time factor and for interaction.

For the linolenic acid, the hybrid Hyola 43 presented the lowest concentration of this variable, reaching the percentage of $77.3 \mathrm{~g} \mathrm{~kg}^{-1}$, while Hyola 61 showed the highest percentage of this fatty acid, obtaining $92.7 \mathrm{~g} \mathrm{~kg}^{-1}$. Hyola 571 had a mean of $86.3 \mathrm{~g} \mathrm{~kg}^{-1}$ and was statistically significant to Hyola 43 and 61 (Table 2).

Linolenic acid or omega-3 has three unsaturations in its molecule and this lipid is also part of the group of essential fatty acids in the human diet because it is not synthesized by the human body.

Searching for various oils, [23] verified the presence of $101.0 \mathrm{~g} \mathrm{~kg}^{-1}$ of linolenic acid in canola oil.[22] obtained values of $100.2 \mathrm{~g} \mathrm{~kg}^{-1}$ and $94.6 \mathrm{~g} \mathrm{~kg}^{-1}$ of linolenic acid in two varieties of canola, and $95.0 \%$ and $116.5 \%$ in two varieties of rapeseed. The values of linolenic acid found in this experiment are lower than those mentioned.

According to the time evolution, there was a tendency to exchange values between oleic (one saturation) that increased and linoleic (two saturations) that decreased, expected physiological process. This process is interesting for the use of the oil as fuel and would harm the oil if the final destination was the human food. Considering the results of dependent, quantitative and qualitative variables, the best sowing time of canola would be between the second fortnight of April and the first week of May.

\section{CONCLUSION}

There was a significant difference for the hybrids in the variables oil content, induction time and in the stearic, linoleic and linolenic contents. Highlighting Hyola 43.

There was a significant difference for the periods in the grain yield, oil content, oil yield, and induction time and in the palmitic, stearic, oleic and linoleic contents. The most interesting seeding season would be between April 16th and May 2nd.

\section{ACKNOWLEDGEMENTS}

To the InstitutoAgronômico do Paraná (Iapar) for the availability of climatic data and Capes for the Masters scholarship?

\section{REFERENCES}

[1] M. Parikka, "Global biomass fuel resources". BiomassBioenerg., v.27(6), p.613-620, 2004.

[2] A. Borsoi, R. F. Santos, C. E. C.Nogueira, D.Secco, M. A. A. de Andrade, P. R. Lima, and A. P. F. da Costa, "Technical and economic feasibility of biodiesel production by family farmers",Afr. J. Agric. Res., v.8 (42), p.5204-5210, 2013.

[3] Embrapa. Resultados da canola no Brasil, 2015. Available from <https://www.embrapa.br/busca-de-noticias/-/noticia/6815550/resultados-da-canola-no-brasil> Access on Nov. 14, 2015.

[4] L. E. Panozzo, J. Zuchi, F. D. daSilva, L. B.Pinto, D. C. F. dosDias, W. S.Barros, and G. O.Tomm, "Evaluation of some hybrids of canola in function of sowing dates in Viçosa, MG, Brazil”,Afr. J. Agric., v.9 (32), p.2488-2494, 2014.

[5] S. B. Lee, K. H.Han, J. D.Lee, and I. K.Hong, "Optimum process and energy density analysis of canola oil biodiesel synthesis”,J. Ind. Eng.Chem., v.16 (6), p.1006-1010, 2010.

[6] G. O. Tomm, S. Wiethölter, G. A. Dalmago, andH. P.dos Santos, "Tecnologia para produção de canola no Rio Grande do Sul”, Passo Fundo: Embrapa Trigo, Documento 113. 39p. 2009.Avaliablefrom<http://www.cnpt.embrapa.br/biblio/do/p_do113.htm >Acess on Jan. 16, 2015.

[7] G. A. Dalmago, G. R. da S. A.Cunha, J. L. F. Pires, A. L.Müller,and L. M.Bolis, "Aclimatação ao frio e dano por geada em canola",Pesq. Agropec. Bras., v.45(9), 2010.

[8] G. L. Luz, S. L. P. Medeiros, G. O.Tomm, A.Bialozor, A. D. doAmaral,and D.Pivoto, "Temperatura base inferior e ciclo de híbridos de canola",Cienc.Rural, v. 42 (9), p.1549-1555, 2012. Available from

<http://www.scielo.br/scielo.php?script=sci_arttext\&pid=S0103-84782012000900006\&lng=en\&nrm=iso>Access on June25, 2016. 
[9] AOCS-American Oil Chemists Society. Official Methods and Recommended Practices of the American Oil Chemist's Society (Ca 540). Champaign: AOCS, 2004.

[10] R. A. Ferrari, V. da S.Oliveira, andA. Scabio, "Biodiesel de soja - Taxa de conversão em ésteres etílicos, caracterização físicoquímica e consumo em gerador de energi”, Quim. Nova, v.28 (1), p. 19-23, 2005.

[11] D. F. Ferreira, "Sisvar: a computerstatisticalanalysis system", Cienc.Agrotec., v.35(6), p.1039-1042, 2011.

[12] E. Fochesatto, A. H. Nied, H.Bergamaschi, G. A.Dalmago, D. G. Pinto, S.Kovaleski, G. R. da Cunha, and J. A.Gouvea, "Interception of solar radiation by the productive structures of spring canola hybrids",Cienc.Rural, v. 46(10), 2016.

[13] C. S. Suzana, F. T. da Rosa, E. R.Kluge, J. M.Frighetto, P.Frizon, F. B. Martins, A.Brunetto,andG. O.Tomm, "Avaliação do desenvolvimento fenológico da canola (BrassicanapusL. var. oleífera) na região norte do Rio Grande do Sul”, In: Simpósio Latino Americano de Canola, I. 2014, Passo Fundo, BR. Anais. Brasília: Embrapa/Abras Canola, 2014. CD-Rom.

[14] Seab - Secretaria da Agricultura e do Abastecimento. Departamento de Economia Rural - DERAL. Estimativa de safra. Avaliblefrom<http://www.agricultura.pr.gov.br/arquivos/File/deral/pss.xls>Acesson Jan. 18, 2014.

[15] G. O. Tomm, R. W. C. Raposo, T. A. F. de Souza, J. T. de L. Oliveira, E. H. S. Raposo, C. P. da S. Neto, A. C. Brito, R. de S. Nascimento, A. W. S. Raposo,andC. F. de Souza, "Desempenho de genótipos de canola (BrassicanapusL.) no Nordeste do estado da Paraíba, Nordeste do Brasil”, Boletim de Pesquisa e Desenvolvimento Online 65. Embrapa Trigo. Passo Fundo - RS. 11 p. 2008. Avaliablefrom<http://www.cnpt.embrapa.br/biblio/bp/p_bp65.htm>Acesson Jan. 21, 2015.

[16] A. M. A. Melgarejo, J. B. Duarte Junior, A. C. T.Da Costa, E. J.Mezzalira, A. L. Piva, andA.Santin, "Características agronômicas e teor de óleo de canola em função da época de semeadura”,Rev. Bras. Eng. Agríc. Ambient. v.18(9), p.934-938, 2014.

[17] L. Coll,andL. M.Larrosa, "Efecto de la fecha de siembra y el ciclo sobre elrendimiento de colza", Cultivos de Invierno, v.1, p.33-37, 2010.

[18] R. S. Oliveira, S. M. Palácio, E. A. Silva, C. Primieri, F. Garbelotti, C. K. Schuroffand B. Zanini, “Avaliação da Estabilidade Oxidativa de Óleos Para Produção do Biodiesel”, II Simpósio de Bioenergia e Biocombustíveis do Mercosul. 2014.Available from<http://cac-php.unioeste.br/eventos/simbiomercosul/anais/arquivos/54.doc>Acesson Jan. 16, 2015.

[19] L. Brock, M. R. Nogueira, C.Zakrzevski, F. C.Corazza, M. L.Corazza,andJ. V. de Oliveira, "Determinação Experimental da Viscosidade e Condutividade Térmica de Óleos Vegetais”,Cienc. Tecnol. Aliment. v.28(3), p.564-570, 2008.

[20] B. Esteban, J. R. Riba, G. Baquero, A. AntoniRius, and R. Puig, “Temperature Dependence Of Density And Viscosity Of Vegetable Oils", Biomass Bioenerg, v.42, p.164-171, 2012.

[21] C. C. Osawa,and L. A. G. Gonçalves, "Titulação potenciométrica aplicada na determinação de ácidos graxos livres de óleos e gorduras comestíveis”, Quim Nova, v.29 (3), p.593-599, 2006.

[22] S. D. Lee, B. S.Nohn, S. Y.Bae, andK, Kim, "Characterization of fatty acids composition in vegetable oils by gas chromatography and chemometrics",Anal. Chim.Acta., v. 358(2), p.163-175, 1998.

[23] J. M. Snyder, E. N. Frankel, and E.Selke, "Capillary Gas Chromatographic Analyses of Headspace Volatiles from Vegetable Oils".JAOCS, v.62(12), p.1675-1679, 1985.

[24] R. C. Zambiazi, R.Przybylski, M. W.Zambiazi, and C. B.Mendonça, "Fatty Acid Composition Of Vegetable Oils And Fats",B. CEPPA, v. 25(1), p.111-117, 2007.

[25] R. P. F. Guiné,and F.Henrques, "O Papel dos Ácidos Gordos na Nutrição Humana e Desenvolvimentos Sobre o Modo Como Influenciam a Saúde”, Millenium, 40: 7-21. 2011. 